\title{
The impact of US fresh milk production standards on dairy trade*
}

\author{
P. Dorian Owen ${ }^{\mathrm{a}}$ and Niven Winchester ${ }^{\mathrm{a}, \mathrm{b}}$ \\ ${ }^{a}$ Department of Economics, University of Otago \\ ${ }^{\mathrm{b}}$ Joint Program on the Science and Policy of Global Change, Massachusetts Institute of Technology
}

* This research is part of the collaborative research project "Assessment of the impacts of nontariff measures on the competitiveness of the EU and selected trade partners - NTM-Impact", co-financed by the European Commission under its 7th Framework Program (project contract No. 227202).

Contact details:

Dorian Owen email: dorian.owen@otago.ac.nz tel: 6434798655
Niven Winchester

email: niven@mit.edu

tel: 6172536958 


\section{Abstract}

We analyse the impact of proposed changes in US legislation to allow greater use of dairy concentrate products in the production of fresh milk products. This change could potentially have a large impact on dairy trade as US tariffs on concentrated dairy products are low relative to average dairy tariffs. Our investigation builds a global model that identifies six dairy commodities and includes a detailed specification of the production of fresh milk products. We find that proposed changes in US legislation may lead to large proportional changes in US imports of concentrated milk products from some sources. However, as proposed changes in US regulations will only facilitate a small increase in the use of concentrated milk products in the production of fresh milk products, there are only small changes in global dairy production. We supplement results from our simulation model with a gravity analysis. Our results indicate that trade in concentrated milk products is positively related to aggregate dairy tariffs and negatively related to concentrated milk tariffs. This suggests that large tariffs on some dairy commodities influence the overall pattern of dairy trade.

Keywords: dairy trade, concentrated milk products, non-tariff barriers, US milk production standards, numerical simulation, gravity modelling 


\section{INTRODUCTION}

The dairy sector is one of the more protected sectors in the world. As the US imposes a number of high tariffs and restrictive tariff-rate quotas (TRQs) on dairy commodities, these instruments are likely to have a larger impact on trade than domestic standards, which act as non-tariff barriers to trade. Two exceptions include milk protein concentrate and whey protein concentrate (henceforth known as concentrated dairy products), which attract US tariffs of $0.1 \%$ and $8.5 \%$ respectively (and are not subject to TRQs). Milk protein concentrate is a concentrated milk product manufactured from fresh milk. It contains a high level of protein and is used in the production of beverages and foods, including infant formulas, yogurts, some cheeses and bakery products. Whey protein concentrate is mainly used as a food supplement and a dietary supplement for improving athletic performance.

Dairy production in the US is governed by the Grade A Pasteurized Milk Ordinance (PMO), which was adapted from the Standard Milk Ordinance developed by the Public Health Service in 1924. The PMO was last revised in 2007 and is published by the US Food and Drug Administration (FDA). The PMO sets minimum standards for the production and transportation of Grade A milk from the farm to the dairy plant. Regulations include standards for the construction and the cleanliness of the milking facility, handling, and maximum bacteriological limits. Grade A dairy farms are inspected regularly. Grade A milk can be used in any dairy product, including fresh milk products. Milk that does not satisfy Grade A standards, but meets less stringent standards, is classified as Grade B (manufacturing grade milk). Grade B milk can be used only in the production of cheese, butter and nonfat dry milk. Due to prohibitive costs, foreign dairy producers outside the US are not Grade A certified, which restricts the use of foreign dairy products in the US.

In partial response to a citizen petition initiated by the National Yogurt Association, the FDA is considering modifying the standards for yogurt production (Docket No. FDA-2000-P- 
0126). Proposed rule changes would, under certain conditions, allow the optional use of any safe and suitable milk-derived ingredient to contribute to the non-fat solids component of yogurt, and permit reconstituted forms of milk as a basic ingredient in yogurt manufacturing. Essentially, these changes would allow yogurt producers to substitute milk protein concentrate and whey protein concentrate for US fresh milk that meets Grade A standards (Hardin, 2009). The legislation change would affect trade by opening a pathway for foreign dairy products to be used in yogurt manufacturing.

Based on proposed changes to US yogurt manufacturing, this paper analyses the impact of a change in US legislation to allow greater use of concentrated dairy products in the production of fresh milk products. Our analysis is built on a bespoke global model that identifies six dairy commodities (fresh milk products, cheese, whole milk powder, skim milk powder, whey powder, and butter). In addition to identifying the EU and the US, the model identifies New Zealand, which is the EU's major foreign competitor in the US market. Remaining regions are grouped in a rest-of-the-world composite. To complement the simulation model, we also examine gravity model estimates of the effects of dairy tariff rates on imports of concentrated dairy products.

This paper has four further sections. Section 2 describes our modelling framework. Our data sources are detailed in Section 3. Simulation results are discussed in Section 4 and the results of the gravity analysis in Section 5 . The final section concludes.

\section{MODELLING FRAMEWORK}

Our numerical simulations employ a version of the 'GTAP7inGAMS' model tailored to suit our needs. GTAP7inGAMS is programmed using the General Algebraic Modelling System (GAMS). GTAP7inGAMS is a static, perfectly competitive, multi-regional representation of the global economy that determines the production and allocation of goods. 
Rutherford (2005) describes the model in detail. Salient features of the model and modifications to facilitate a rigorous analysis of dairy trade are outlined below. ${ }^{1}$

In GTAP7inGAMS, production technologies exhibit constant returns to scale and product and factor prices adjust to maintain zero profits. Output in each sector is governed by a Leontief nest of an intermediate input composite and a constant elasticity of substitution (CES) primary factor composite. The intermediate input composite is derived from a further Leontief aggregation of different products (which are themselves composites of domestic and imported varieties). Specifically, production in sector $i, Y_{i}$, is determined by:

$Y_{i}=\min \left\{a_{i 1} z_{i 1}, \ldots a_{i J} z_{i J}, g_{i}^{Y}\left(\sigma_{i}^{Y} ; x_{i 1}, \ldots, x_{i F}\right)\right\}$

where $z_{i j}$ is the quantity of good $j(j \in 1, \ldots, J)$ used as an intermediate input into sector $i, a_{i j}$ is the inverse of the unit input requirement for good $j$ needed in production of good $i, x_{i f}$ is the quantity of factor $f$ employed by sector $i(f \in 1, \ldots, F), \sigma_{i}^{Y}$ is the elasticity of substitution among primary factors, and $g$ is a generic production function.

Private consumption $(P C)$ in GTAP7inGAMS is governed by a Cobb-Douglas function allocating expenditure across goods, which are composites of domestic and imported varieties:

$P C=g^{P C}\left(C_{1}, \ldots, C_{I}\right)$

where $C_{i}$ is consumption of commodity $i(i \in 1, \ldots, I)$.

Important empirical observations not replicated in standard trade models include intraindustry trade and failure of the law of one price for traded goods. Accordingly, following

\footnotetext{
${ }^{1}$ The GTAP database is packaged with a model programmed using the General Equilibrium Modelling PACKage (GEMPACK). Readers familiar with GEMPACK should note that there are several differences between GTAP7inGAMS and the GEMPACK version of the GTAP model.
} 
Armington (1969), imports in GTAP7inGAMS are differentiated by country of origin, and composite imports are differentiated from domestic production using separate CES functions. Elasticity parameters for our import specification are sourced from Hertel et al. (2007). The composite of domestic and imported varieties for good $i\left(D M_{i}\right)$ is given by:

$$
D M_{i}=g_{i}^{D M}\left(\sigma_{i}^{D M} ; D_{i}, g_{i}^{M}\left(\sigma_{i}^{M} ; M_{i 1}, \ldots, M_{i R}\right)\right)
$$

where $D_{i}$ is the quantity of good $i$ sourced domestically, $M_{i r}$ denotes imports of good $i$ from region $r(r \in 1, \ldots, R)$, and $\sigma_{i}^{D M}$ and $\sigma_{i}^{M}$ are, respectively, elasticities of substitution between domestic production and aggregate imports, and imports from different regions. As import shares differ across intermediate input use and private demand, separate CES aggregators are included for the two demand sources.

A limitation when using GTAP7inGAMS for dairy trade analysis is that the GTAP database identifies only two sectors related to dairy production: fluid milk and processed dairy. Building on estimates from Mraz and Matthews (2007) we extend the GTAP database to identify six dairy commodities: fresh milk products (fmp), cheese (chs), whole milk powder (wmp), whey powder (whp), skim milk powder (smp), and butter (but). Whey powder includes milk protein concentrate and whey powder concentrate, which are key commodities for our analysis. Marz and Matthews (2007) detail procedures to provide production, trade and input data for all six dairy commodities for all regions included in the GTAP database. However, due to concerns about the reliability of their estimates, the full set of data was not publically released. We supplement data from Mraz and Matthews (2007) with data from other sources to complete our analysis, as detailed below.

An important feature of dairy production is that fluid milk contains fixed proportions of protein and fat (Cox et al., 1999; Zhu et al., 1999; Bouamra-Mechemache et al., 2002; and Charteris and Winchester, 2010). This influences producer substitution between processed 
dairy commodities, which use dairy protein and fat in different proportions. Following Charteris and Winchester (2010), we augment the standard GTAP7inGAMS production function to include a processed dairy sector that produces all processed dairy except fresh milk products using a series of nested constant elasticity of transformation (CET) functions. The nested CET functions can be expressed as:

$Y_{d}^{*}=g\left(\sigma_{1}^{T} ; Y_{c \mathrm{~h} s,} Y_{w m p} g\left(\sigma_{2}^{T} ; z\left(\sigma_{3}^{T}, Y_{s m p}, Y_{w \mathrm{~h} p}\right), Y_{b u t}\right)\right)$

where $Y_{d}^{*}$ is the production of processed dairy commodities excluding fresh milk products, $\sigma_{n}^{T}$ is the elasticity of transformation at level $n$, and $Y_{k}$ is the production of dairy commodity $k(k$ $\in$ chs, wmp, smp, whp, but).

The production of processed dairy products excluding fresh milk products is depicted in Figure 1. In the first level of the nest, dairy production is allocated to cheese, whole milk powder and a protein-fat composite. The protein-fat composite is divided into butter and protein in the second level of the nest, and in the third level of the nest protein is divided into skim milk powder and whey products. Transformation possibilities at the first, second and third levels are governed by elasticity of transformation parameters $\sigma_{1}^{T}, \sigma_{2}^{T}$, and $\sigma_{3}^{T}$, respectively. Reflecting fixed proportions of fat and protein embodied in fluid milk, we set $\sigma_{2}^{T}=0$ and, following Charteris and Winchester (2010), we set $\sigma_{1}^{T}=3$ and $\sigma_{3}^{T}=5$.

We specify a separate production function for fresh milk products to allow us to focus on intermediate inputs used in the production of this commodity. Production of fresh milk products is governed by a "standard" production function, as outlined by equation (1), but we separately track each dairy commodity used in the production of fresh milk products. For US production of fresh milk products, to reflect current legislation, we assume that all intermediate inputs are sourced domestically. 
Building on proposed changes to yogurt production, we consider greater use of whey powder in the production of US fresh milk products, which can be sourced domestically or from abroad. We represent such a change in legislation by increasing the quantity of whey powder used as an intermediate input into fresh mill production by $50 \%$, which replaces fresh milk inputs. This shock represents a small absolute change, as the value of whey powder used in US fresh milk products in the base data is around $1.5 \%$.

\section{DATA}

GTAP7inGAMS draws on version 7 of the Global Trade Analysis Project (GTAP) database (Narayanan and Walmsley, 2008). The database distinguishes 113 regions and 57 sectors for 2004, accounts for input-output relations among sectors, and includes a full set of bilateral trade flows. For our purposes, we aggregate the database to identify the US, the EU, New Zealand and the rest of the world (ROW). The EU and New Zealand are the two largest dairy exporters to the US and account for $58 \%$ and $18 \%$, respectively, of the value of US dairy imports (USITC, 2010).

As noted above, dairy production in the GTAP database is characterised by a raw milk sector and a processed dairy sector, where raw milk serves as an intermediate input into the production of processed dairy commodities. To identify six processed dairy commodities, we source production values from Mraz and Matthews (2007, Table 4.2.1.1). We further augment the GTAP7 database using data on US dairy imports, tariffs and TRQs from the US WTO Integrated Data Base, and data on the input-output structure of dairy production from BEA (1992). TRQs are converted to ad valorem tariff equivalents following Bouët et al. (2006). We also identify five non-dairy sectors, including Agriculture, Manufacturing and Services. Aggregation in our model is summarised in Table 1. 
Production values for the six dairy commodities in 2004 US dollars are presented in Table 2. EU dairy production is valued at $\$ 189$ billion, which represents $41 \%$ of global production. In other regions, dairy production in the US is $\$ 73$ billion (31\% of global production), $\$ 4$ billion in New Zealand (1\%) and \$154 billion (27\%) in ROW. Globally, fresh milk products account for 16\% (\$84 billion) of processed dairy production, but this figure varies markedly across regions. In the EU, fresh milk products account for $22 \%$ of national dairy and the corresponding figure for New Zealand, which mainly produces for export markets, is 5\%. The EU produces \$18 billion dollars of whey powder, 8\% of the value of EU dairy production. The US ( $\$ 13$ billion, 15\%) and New Zealand ( $\$ 0.9$ billion, 15\%) produce less whey powder, but production of this product accounted for a larger proportion of national dairy production in these countries than in the EU. Cheese production accounts for the largest share of national dairy production - around one-third - in both the EU and the US.

US dairy imports in 2004 US dollars are displayed in Table 3. Products from the EU account for 58\% (\$891.5 million) of total US dairy imports, while commodities from New Zealand and Rest of World account for, respectively, 18\% (\$278.3 million) and 24\% (\$376.3 million) of aggregate US imports. Turning to the commodity composition of US dairy imports, cheese products account for $92 \%$ of the value imports from the EU and $61 \%$ of the value of imports from Rest of World. US dairy imports from New Zealand are dominated by whey powder (60\%), while whey powder accounts for only $2 \%$ and $11 \%$, respectively, of value of imports from the EU and Rest of World.

\section{SIMULATION RESULTS}

We examine the impact of a change in regulations that allows US fresh milk producers to replace fresh milk inputs with whey powder inputs. Changes in production measured in millions of 2004 US dollars at constant prices are presented in Table 4. Production of whey 
powder increases in all regions, reflecting increased US demand for this commodity. Whey powder production increases by \$23 million in both the US and EU, \$1 million in New Zealand, and \$28 million in the ROW, which represent proportional production changes of between $0.1 \%$ and $0.2 \%$. There is a relative large decrease \$134 million (1.6\%) in US production of fresh milk products. This is because a large proportion (15\%) of the production of fresh milk products is used as an intermediate input within that sector, and our shock allows producers to replace fresh milk inputs with whey powder inputs.

Under our production structure, whey powder production can be increased by increasing production of dairy commodities. Consequently, cheese, whole milk powder and butter output increase in all regions. Skim milk powder decreases in all regions, as a greater share of the protein composite is channelled into whey powder production than in the base data. Aggregate dairy production decreases by $\$ 95$ million in the US, driven by a decrease in fresh milk production, and increases in other regions. Proportional changes in aggregate dairy production are small (e.g., the \$47 million increase in EU dairy productions represents an increase of $0.02 \%)$.

Changes in US imports, also measured in millions of 2004 US dollars at constant prices, are presented in Table 5. US imports of whey powder increase by $\$ 72$ million, with an additional \$32 million imported from the EU, \$2 from New Zealand and \$37 from the ROW. Due to the small amount of whey powder products currently shipped from the EU to the US, the $\$ 32$ million rise in US imports from the EU represents a $288 \%$ increase. US whey powder imports from New Zealand, which supplies three-quarters of US whey powder imports in the base data, represent a $0.7 \%$ increase, while those from the ROW increase by $62 \%$. Changes in aggregate US dairy imports from the EU, New Zealand and the ROW are 3.6\%, $0.6 \%$ and $9.9 \%$. 


\section{GRAVITY ANALYSIS}

To complement the results from the simulations reported in section 4, we examine econometrically the effects of own tariff rates and the tariff equivalent of tariffs and TRQs applying on aggregate dairy products on trade flows for concentrated dairy products. A sectoral gravity model provides a convenient framework for testing the hypothesis that high overall dairy protection results in greater trade in concentrated dairy products.

We use the following single-equation log-linear version of the conventional gravity model applied to panel data on trade flows for concentrated dairy products (whey protein concentrate and milk protein concentrate):

$$
\ln \left(x_{i j t}\right)=\alpha_{0}+\alpha_{1} \ln \left(\text { otrf }_{i j t}\right)+a_{2} \ln \left(\text { dtrf }_{i j t}\right)+\beta_{1} \ln \left(\text { distance }_{i j}\right)+\beta Z_{i j}+\gamma_{i}+\eta_{j}+\theta_{t}+\varepsilon_{i j t}
$$

where $x_{i j t}$ represents exports of concentrated dairy products from country $i$ to country $j$ in year $t$. The ad valorem own tariff is represented by otrf and the ad valorem equivalent of tariffs and TRQs on dairy products by dtrf. Observable factors affecting bilateral trade costs include the distance between countries $i$ and $j$, distance $_{i j}$, a vector of dummy variables, $Z_{i j}$, equal to one if $i$ and $j$ share a common border (contiguous), a current or past colonial link (colony), a common official language (language), or are both partners in a free trade area: the EU (fta_eu), NAFTA (fta_nafta), MERCOSUR (fta_merc) or the Australia-New Zealand Closer Economic Relations (CER) agreement (fta_anz). Trade flows do not depend solely on bilateral trade costs; hence, multilateral trade resistance (Anderson and van Wincoop, 2003) is accounted for by including country-specific exporter $\left(\gamma_{i}\right)$ and importer $\left(\eta_{j}\right)$ fixed effects (Mátyás, 1997; Feenstra, 2002). ${ }^{2}$ Year fixed effects $\left(\theta_{t}\right)$ are also included. The model does

\footnotetext{
${ }^{2}$ Including separate exporter and importer fixed effects does not control for idiosyncratic bilateral factors affecting trade. Consequently, some studies (e.g., Carrère, 2006; Westerlund and Wilhelmsson, 2011) include country pair $(i, j)$ fixed effects. However, this is appropriate only if there is significant variation over time in the explanatory variables of interest (Baldwin and Taglioni, 2006), which is not the case for any of the variables in our dataset, including the own tariff rate and the aggregate dairy tariff.
} 
not include variables reflecting exporter $i$ 's production and importer $j$ 's consumption of concentrated dairy products, the relevant 'size' variables in this context, primarily due to lack of data. Such time-varying country-specific factors can however be incorporated by including time-varying exporter- and importer-specific dummy variables (denoted as 'Country TV' in Table 6), as well as year fixed effects. This provides a robustness check on the results from models specified with exporter and importer fixed effects.

The model is fitted using data for 15 exporters and 22 importers, the main trading nations in the market for concentrated dairy products, for the years 2005-2009. ${ }^{3}$ Data on bilateral trade flows (measured as imports from the partner to the reporter, in1000 US\$) are sourced from the United Nation's Commodity Trade Statistics Database, ad valorem own tariffs for concentrated dairy products are taken from the Market Access Map database, and ad valorem tariff equivalents of tariffs and TRQs for aggregate dairy products are sourced from the GTAP database.

Geographical distance, distance, is measured using the population-weighted average (harmonic mean) of bilateral distances between major cities in the two countries of interest (Head and Mayer, 2002); these data are available from the Centre d'Etudes Prospectives et d'Informations Internationales (CEPII). ${ }^{4}$ Data for the dummy variables contiguous, colony and language are also from CEPII.

The estimation method adopted when analysing gravity models can have important effects for parameter estimates and consequent policy conclusions; however, there is no clear consensus on which is the best estimator to adopt in general (e.g., Santos Silva and Tenreyro, 2006; Schaefer et al., 2008; Martin and Pham, 2008; Burger et al., 2009; Siliverstovs and

\footnotetext{
${ }^{3}$ The exporters included are: Argentina, Austria, Australia, Belgium, Canada, Denmark, Finland, France, Germany, Ireland, Netherlands, New Zealand, Poland, UK, US. Importers included are: Australia, Belgium, Brazil, Canada, China, Egypt, France, Germany, Indonesia, Japan, Malaysia, Mexico, Morocco, Netherlands, Philippines, Russia, Singapore, Spain, Thailand, UK, US, Vietnam

${ }^{4}$ CEPII data are available at http://www.cepii.fr/anglaisgraph/bdd/distances.htm.
} 
Schumacher, 2009; Westerlund and Wilhelmsson, 2011; Martínez-Zarzoso, 2013). ${ }^{5}$ We therefore estimate the parameters using different methods (least squares, Poisson pseudomaximum-likelihood estimation and two-step estimation) to help assess the degree of robustness of the results. Given strong evidence of heteroskedastic residuals in the fitted models, heteroskedasticity-robust standard errors are reported; ${ }^{6}$ standard errors are adjusted for clustering at the exporter-importer-pair level.

The results reported in Table 6, columns (1)-(4) are obtained using ordinary least squares (OLS) estimation, adopting the conventional ad hoc adjustment of adding a small positive constant, such as one, to variables that take zero values for some observations, to allow the use of a logarithmic transformation. This affects not only the dependent variable, trade flows, but also the tariff variables. Although widely used, this has the drawback that the point estimates of the coefficients (which are conventionally still interpreted as approximate elasticities) are sensitive to the choice of the added constant (Flowerdew and Aitkin, 1982; Burger et al., 2009). ${ }^{7}$

Results in column (5) are obtained using the Poisson pseudo-maximum likelihood (PPML) estimator (Santos Silva and Tenreyro, 2006; Westerlund and Wilhelmsson, 2011). This approach avoids the arbitrary adjustment in transforming the dependent variable; it also helps address problems due to heteroskedasticity-induced dependence between the explanatory variables and the error terms, which causes least squares estimates to be biased and inconsistent. The PPML estimator is based on the assumption that the conditional variance is

\footnotetext{
${ }^{5}$ Uncertainty over model specification has received relatively less explicit attention, although Yamarik and Ghosh (2005) conduct an extreme-bounds analysis of variables commonly used in gravity analysis, based on OLS estimates. If different variables proxying trade costs are highly correlated, then point estimates and their statistical significance, for any given choice of estimation method, are likely to be sensitive to the combination of variables included in the model.

${ }^{6}$ For example, a Breusch-Pagan test convincingly rejects the null of homoskedastic errors in the models in Table 6, columns (1)-(4), with all $p$-values $=0.0000$.

${ }^{7}$ Varying the added constant in the logarithmic transformations in our model does affect the point estimates, especially on the tariff variables. However, the corresponding levels of statistical significance of these estimates are much less affected than the numerical values of the point estimates; a similar pattern is observable in Table 2 of Burger et al. (2009).
} 
proportional to the conditional mean of the (non-logged) trade flows. If this is not the case, the estimator is still consistent provided the conditional mean is correctly specified, but heteroskedasticity effects are not fully resolved and inference based on heteroskedasticityrobust standard errors is recommended (Santos Silva and Tenreyro, 2006). Following Westerlund and Wilhelmsson (2011), we calculate standard errors for the Poisson estimates based on 100 bootstrap replications.

Neither OLS nor the Poisson model considers zero trade values to be the result of selection. From this perspective, zeros for different exporter-importer pairs may be associated with different levels of trade costs and hence different probabilities of non-zero trade flows. Consequently, although stronger distributional assumptions are required, variants of Heckman’s (1979) sample selection framework have become popular in estimating gravity models. In the current context, selection models are likely to be less useful as, given the very specific commodity focus, the sample of exporters and importers has already been truncated for tractability. In two-step estimation, a probit (propensity to trade) model is estimated in the first step, followed by a second-step estimation of the main gravity equation adding a variable that adjusts for the sample selection probability. Results for the second-step equation are reported in column (6) based on excluding colony on the basis that colonial ties are likely to affect the probability of trading but not the size of the trade flow (a view supported by the OLS results).

We focus on the sign and statistical significance of the estimated parameters on the own tariff rate and aggregate dairy tariff rates. For the OLS estimates, the coefficients on the own tariff rates are negative but not statistically significant in the full models in columns (1) and (3). ${ }^{8}$ However, simplifying the models by removing other variables that are not statistically significant, individually or jointly ( $p=0.793$ for the restrictions imposed in column (2) and $p$

\footnotetext{
${ }^{8}$ This is at least partly due to the high degree of collinearity between the own tariff rate and the importer fixed effects. Regressing $\ln (1+$ ortf $)$ on the set of importer fixed effects gives an adjusted $R^{2}$ value of 0.991 .
} 
$=0.811$ in column (4)), reduces the standard error of the estimates on the own-rate coefficient, so that it becomes significant at the $5 \%$ level. The coefficient on the dairy tariff has a statistically significant positive effect on imports (with $p$-values in the range 0.045 to 0.066), regardless of the form of the country dummies used to capture multilateral resistance or whether the model is estimated in its full or simplified form. The other statistically significant coefficients in the models estimated using OLS have the expected signs, although for New Zealand and Australia, CER membership has a negative effect on bilateral trade in concentrated dairy products.

The PPML estimates in column (5) markedly differ from those of OLS for several of the parameters, in line with similar comparisons in previous studies (e.g., Santos Silva and Tenreyro, 2006; Siliverstovs and Schumacher, 2009; Westerlund and Wilhelmsson, 2011). For example, as is common in other studies using PPML, the absolute value of the distance elasticity is drastically reduced, and is no longer statistically significant in column (5). The estimates of the tariff coefficients are less affected but are more precisely estimated using PPML; the estimated coefficient on the own tariff is numerically similar to OLS estimates but is now statistically significant at the $0.1 \%$ level, and the dairy tariff coefficient is significant at the $5 \%$ level, although with a smaller point estimate near unity. ${ }^{9}$ For the Heckman results, for which the main model estimates are reported in Table 6, column (6), the tariff coefficients have the expected signs but are not statistically significant.

Overall, given the many unresolved issues relating to the appropriate specification and estimation of gravity equations, especially for panel sectoral data, we cautiously interpret these results as providing some support to the simulation results in section 4 .

\footnotetext{
${ }^{9}$ Because of the adjustments to the logarithmic transformation, we are wary of overemphasizing the quantitative significance of the tariff effects.
} 


\section{CONCLUSIONS}

The US imposes high tariffs on many dairy commodities but low tariffs are applied to some products. Non-tariff measures may have a significant effect on trade in commodities attracting low tariffs. In this respect, US tariffs on many fresh milk products are around 1\% and US tariffs on milk protein concentrate and whey protein concentrate are, respectively, 0.1\% and 8.5\%. These products must also meet stringent domestic standards. Specifically, US fresh milk products can be made only from Grade A-certified fluid milk and it is costly for foreign producers to gain Grade A certification. US regulations also limit the use of dairy concentrates in fresh milk products. This paper analysed a change in US fresh milk standards that allows greater use of concentrated dairy products in fresh milk production, thereby allowing foreign producers to partially circumvent Grade A standards for fresh milk products.

The analysis required construction of a model of global dairy trade and production that included a detailed account of inputs used in the production of fresh milk products. We constructed such a model by extending the GTAP7inGAMS model. We found that proposed changes in fresh milk standards will lead to large proportional changes in US imports of concentrated milk products, but will not lead to large changes in global dairy production. We observe this result because proposed changes in US regulations will facilitate only a small increase in the use of concentrated milk products in the production of fresh milk products. The results from our gravity analysis indicate that trade in concentrated milk products is positively related to aggregate dairy tariffs and negatively related to concentrated milk tariffs, suggesting that large tariffs on some dairy commodities influence the overall pattern of dairy trade.

We conclude that the combined effect of the US Grade A standard and regulations governing production of fresh milk products have a small influence on dairy trade relative to tariffs and TRQs, which are significant for some products. 


\section{REFERENCES}

Anderson, J. E. and E. van Wincoop (2003), 'Gravity with Gravitas: A Solution to the Border Puzzle', American Economic Review, 93, 1, 170-92.

Armington, P. S. (1969), ‘A Theory of Demand for Products Distinguished by Place of Production', IMF Staff Papers, 16, 1, 159-76.

Baldwin, R. and D. Taglioni (2006), 'Gravity for Dummies and Dummies for Gravity Equations’, NBER Working Paper No. 12516 (Cambridge, MA: NBER).

BEA (Bureau of Economic Analysis) (1992), ‘1992 Benchmark input-output table’, US Department of Commerce, Washington, DC.

Bouamra-Mechemache, Z., J.-P. Chavas, T. L.Cox and V. Requillart (2002), 'Partial Market Liberalization and the Efficiency of Policy Reform: The Case of the European Dairy Sector', American Journal of Agricultural Economics, 84, 4, 1003-20.

Bouët, A., Y. Decreux, L. Fontagné, S. Jean and D. Laborde (2006), ‘Tariff data’, in B.V. Dimaranan (ed.), Global Trade Assistance and Protection: The GTAP 6 Data Base. Center for Global Trade Analysis, Purdue University, Chapter 16.D.

Burger M., F. van Oort and G.-J. Linders (2009), 'On the Specification of the Gravity Model of Trade: Zeros, Excess Zeros and Zero-Inflated Estimation', Spatial Economic Analysis, 4, 2, 167-90.

Carrère, C. (2006), 'Revisiting the Effects of Regional Trade Agreements on Trade Flows with Proper Specification of the Gravity Model', European Economic Review, 50, 2, 22347.

Charteris, A. and Winchester, N. (2010), 'Dairy disaggregation and joint production in an economy-wide model', Australian Journal of Agricultural and Resource Economics, 54, 4, 491-507. 
Cox T. L., J. R. Coleman, J.-P. Chavas and Y. Zhu (1999), ‘An Economic Analysis of the Effects on the World Dairy Sector of Extending the Uruguay Round Agreement to 2005', Canadian Journal of Agricultural Economics, 47, 5, 169-183.

Eurostat (Statistical Office of the European Union) (2009), 'External trade data’, European Commission, Luxembourg.

Feenstra, R. C. (2002), 'Border Effects and the Gravity Equation: Consistent Methods for Estimation', Scottish Journal of Political Economy, 49, 5, 491-506.

Ferrantino, M. (2006), 'Quantifying the Trade and Economic Effects of Non-Tariff Measures’, OECD Trade Policy Working Paper No. 28.

Flowerdew, R. and M. Aitkin (1982), 'A Method of Fitting the Gravity Model Based on the Poisson Distribution', Journal of Regional Science, 22, 2, 191-202.

Hardin, P. (2009), 'Yogurt lobby: Kill Grade A dairy rules’, The Milkweed, February 2009, 57.

Head, K. and T. Mayer, (2002), ‘Illusory border effects’, CEPII Working Paper No. 2002-01. Heckman, J. J. (1979), ‘Sample Selection Bias as a Specification Error’, Econometrica, 47, 1, 153-61.

Hertel, T., D. Hummels, M. Ivanic and R. Keeney (2007). 'How Confident Can We Be of CGE-Based Assessments of Free Trade Agreements?', Economic Modelling 24, 4, 611-35. Martin, W. and Pham, C. S. (2008), 'Estimating the Gravity Model when Zero Trade Flows are Frequent', mimeo, Deakin University.

Martínez-Zarzoso, I. (2013), 'The Log of Gravity Revisited', Applied Economics, 45, 3, 31127.

Mátyás, L. (1997), 'Proper Econometric Specification of the Gravity Model’, World Economy, 20, 3, 363-8. 
Mraz, M. and A. Matthews (2007), 'Disaggregating the Dairy Sector in the GTAP database', Presented at the Tenth Annual Conference on Global Economic Analysis, 7-9 June 2007, Purdue University, West Lafayette, Indiana.

Nahuis, R. (2004), ‘One Size Fits All? Accession to the Internal Market; An Industry-Level Assessment of EU Enlargement', Journal of Policy Modeling, 15, 5, 571-86.

Narayanan B. and T. L. Walmsley (eds) (2008), Global Trade, Assistance, and Production: The GTAP 7 Data Base, Center for Global Trade Analysis, Purdue University.

Philippidis, G. and A. Carrington (2005), 'European Enlargement and Single Market Accession: A Mistreated Issue', Journal of Economic Integration, 20, 3, 543-66.

Philippidis, G. and A. I. Sanjuán (2007a), ‘An Examination of Morocco’s Trade Options with the EU', Journal of African Economics, 16, 2, 259-300.

Philippidis, G. and A. I. Sanjuán (2007b), ‘An Analysis of Mercosur’s Regional Trading Agreements', World Economy, 30, 3, 504-31.

Rutherford, T.F. (2005). ‘GTAP6inGAMS: The Dataset and Static Model’, Ann Arbor, MI. Available at URL: http://www.mpsge.org/gtap6/gtap6gams.pdf.

Santos Silva, J. M. C. and S. Tenreyro (2006), 'The Log of Gravity’, Review of Economics and Statistics, 88, 4, 641-58.

Schaefer, K. C., M. A. Anderson and M. J. Ferrantino (2008), 'Monte Carlo Appraisals of Gravity Model Specifications’, Global Economy Journal, 8, 1, Article 2.

Siliverstovs, B. and D. Schumacher (2009), 'Estimating Gravity Equations: To Log or Not to Log?’, Empirical Economics, 36, 3, 645-69.

USITC (United States International Trade Commission) (2010), 'Interactive tariff and trade DataWeb’, Washington, DC.

USDA (United States Department of Agriculture) (2009), 'Global Agricultural Trade System’, Foreign Agricultural Service, Washington, DC. 
Westerlund, J. and F. Wilhelmsson (2011), ‘Estimating the Gravity Model Without Gravity Using Panel Data', Applied Economics, 43, 6, 641-9.

Winchester, N. (2009), 'Is There a Dirty Little Secret? NTBs and the Gains From Trade', Journal of Policy Modeling, 31, 6, 819-34.

Yamarik, S. and S. Ghosh (2005), 'A Sensitivity Analysis of the Gravity Model’, International Trade Journal, 19, 1, 83-126.

Zhu, Y., Cox, T.L, and Chavas, J.-P. (1999), 'An economic analysis of the effects of the Uruguay Round Agreement and full trade liberalization on the world dairy sector', Canadian Journal of Agricultural Economics, 47, 5, 187-200. 
Table 1: Model aggregation

\begin{tabular}{ll}
\hline Sectors & Regions \\
\hline Agriculture & US \\
Raw milk & EU27 \\
Processed dairy & New Zealand \\
$\quad$ Fresh milk products & Rest of World (ROW) \\
Cheese & \\
Whole milk powder & \\
Skim milk powder & \\
Whey powder & \\
Butter & \\
Other food production & \\
Manufacturing & \\
Mining & \\
Services & \\
\hline
\end{tabular}

Table 2: Dairy production, 2004 US\$ million

\begin{tabular}{lrrrrr}
\hline & US & EU & $\begin{array}{r}\text { New } \\
\text { Zealand }\end{array}$ & ROW & Total \\
\hline Fresh milk products & 8,542 & 47,741 & 245 & 27,958 & 84,485 \\
Cheese & 27,429 & 71,986 & 873 & 38,450 & 138,738 \\
Whole milk powder & 10,338 & 27,116 & 1,462 & 38,604 & 77,521 \\
Skim milk powder & 13,699 & 23,994 & 726 & 32,051 & 70,470 \\
Whey products & 13,379 & 18,367 & 918 & 17,471 & 50,135 \\
Butter & 10,933 & 30,098 & 682 & 25,940 & 67,653 \\
Total & 73,386 & 189,204 & 4,225 & 154,535 & 421,350 \\
\hline
\end{tabular}

Source: Production shares in Mraz and Matthews (2007, Table 4.2.1.1) applied to the GTAP 7 database (Narayanan and Walmsley, 2008). 
Table 3: US dairy imports by source, 2004 US\$ million

\begin{tabular}{lrcrr}
\hline & EU & New Zealand & ROW & Total \\
\hline Fresh milk products & 41.9 & 0.7 & 12.3 & 54.9 \\
Cheese & 819.0 & 69.0 & 228.8 & 1116.8 \\
Whole milk powder & 2.6 & 6.1 & 51.9 & 60.6 \\
Skim milk powder & 0.1 & 0.4 & 1.6 & 2.1 \\
Whey products & 11.6 & 168.0 & 40.3 & 219.9 \\
Butter & 16.3 & 34.2 & 41.4 & 91.9 \\
Total & 891.5 & 278.3 & 376.3 & 1546.2 \\
\hline
\end{tabular}

Source: United States International Trade Commission Interactive Tariff and Trade database.

Table 4: Dairy production changes, US\$ million

\begin{tabular}{lccccc}
\hline & US & EU & $\begin{array}{c}\text { New } \\
\text { Zealand }\end{array}$ & ROW & Total \\
\hline Fresh milk products & -133.78 & 5.03 & 0.04 & 2.81 & -125.90 \\
Cheese & 6.03 & 7.62 & 0.13 & 3.81 & 17.59 \\
Whole milk powder & 2.27 & 2.79 & 0.20 & 3.81 & 9.07 \\
Skim milk powder & -1.53 & -4.96 & -0.12 & -5.00 & -11.61 \\
Whey products & 23.62 & 23.46 & 1.38 & 28.33 & 76.79 \\
Butter & 8.92 & 13.14 & 0.52 & 12.23 & 34.81 \\
Total & -94.48 & 47.09 & 2.15 & 45.98 & 0.75 \\
\hline
\end{tabular}

Table 5: Changes in US dairy imports, US\$ million

\begin{tabular}{lcccc}
\hline & EU & New Zealand & ROW & Total \\
\hline Fresh milk products & 0.00 & 0.00 & 0.04 & 0.04 \\
Cheese & 0.32 & 0.03 & 0.06 & 0.41 \\
Whole milk powder & 0.00 & 0.00 & 0.05 & 0.05 \\
Skim milk powder & 0.00 & 0.00 & 0.01 & 0.01 \\
Whey products & 32.49 & 1.71 & 37.32 & 71.52 \\
Butter & 0.00 & 0.05 & 0.06 & 0.11 \\
Total & 32.82 & 1.80 & 37.53 & 72.15 \\
\hline
\end{tabular}




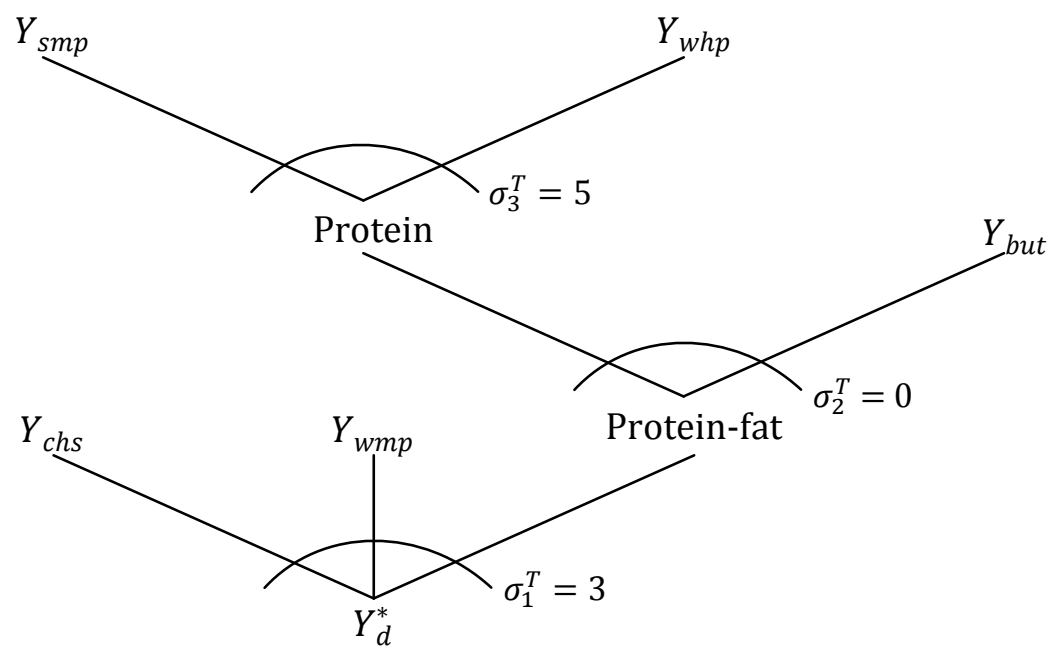

Figure 1: Production of processed dairy products, excluding fresh milk products 
TABLE 6

Gravity Equation Estimates for Trade in Concentrated Milk Products

\begin{tabular}{|c|c|c|c|c|c|c|}
\hline & (1) & (2) & (3) & (4) & (5) & (6) \\
\hline $\ln (1+$ otrf $)$ & $\begin{array}{l}-10.70 \\
(8.199)\end{array}$ & $\begin{array}{r}-14.64^{* *} \\
(4.940)\end{array}$ & $\begin{array}{l}-10.66 \\
(8.658)\end{array}$ & $\begin{array}{r}-14.69^{* *} \\
(5.205)\end{array}$ & $\begin{array}{r}-15.27^{* * *} \\
(3.165)\end{array}$ & $\begin{array}{c}-3.673 \\
(4.837)\end{array}$ \\
\hline $\ln (1+d t r f)$ & $\begin{array}{r}1.845^{\dagger} \\
(0.952)\end{array}$ & $\begin{array}{c}1.889^{*} \\
(0.936)\end{array}$ & $\begin{array}{c}1.853^{\dagger} \\
(1.003)\end{array}$ & $\begin{array}{c}1.897^{\dagger} \\
(0.986)\end{array}$ & $\begin{array}{c}0.987^{*} \\
(0.452)\end{array}$ & $\begin{array}{c}0.513 \\
(0.415)\end{array}$ \\
\hline $\ln ($ distance $)$ & $\begin{array}{l}-1.139^{* * * *} \\
(0.258)\end{array}$ & $\begin{array}{l}-1.106^{* * *} \\
(0.239)\end{array}$ & $\begin{array}{c}-1.134^{* * *} \\
(0.271)\end{array}$ & $\begin{array}{l}-1.103^{* * * *} \\
(0.251)\end{array}$ & $\begin{array}{c}-0.172 \\
(0.100)\end{array}$ & $\begin{array}{c}-0.809^{* * *} \\
(0.121)\end{array}$ \\
\hline language & $\begin{array}{c}0.875^{*} \\
(0.406)\end{array}$ & $\begin{array}{c}0.854^{*} \\
(0.354)\end{array}$ & $\begin{array}{c}0.874^{*} \\
(0.427)\end{array}$ & $\begin{array}{c}0.852^{*} \\
(0.373)\end{array}$ & $\begin{array}{l}1.447^{* * *} \\
(0.167)\end{array}$ & $\begin{array}{c}0.347^{*} \\
(0.157)\end{array}$ \\
\hline contiguous & $\begin{array}{c}-0.265 \\
(0.562)\end{array}$ & & $\begin{array}{c}-0.262 \\
(0.590)\end{array}$ & & $\begin{array}{l}1.227^{* * *} \\
(0.130)\end{array}$ & $\begin{array}{c}0.650^{* * *} \\
(0.240)\end{array}$ \\
\hline colony & $\begin{array}{c}0.161 \\
(0.536)\end{array}$ & & $\begin{array}{c}0.161 \\
(0.563)\end{array}$ & & $\begin{array}{c}-0.445^{*} \\
(0.179)\end{array}$ & \\
\hline fta_eu & $\begin{array}{c}2.390^{* * *} \\
(0.770)\end{array}$ & $\begin{array}{l}2.347^{* *} \\
(0.728)\end{array}$ & $\begin{array}{c}2.449 \text { *** } \\
(0.807)\end{array}$ & $\begin{array}{l}2.405^{* *} \\
(0.762)\end{array}$ & $\begin{array}{l}2.640^{* * * *} \\
(0.413)\end{array}$ & $\begin{array}{l}1.884^{* * *} \\
(0.349)\end{array}$ \\
\hline fta_nafta & $\begin{array}{c}1.441^{\dagger} \\
(0.740)\end{array}$ & $\begin{array}{c}1.087^{\dagger} \\
(0.613)\end{array}$ & $\begin{array}{c}1.452^{\dagger} \\
(0.779)\end{array}$ & $\begin{array}{c}1.094^{\dagger} \\
(0.643)\end{array}$ & $\begin{array}{c}-0.380 \\
(0.337)\end{array}$ & $\begin{array}{c}0.765 \\
(0.484)\end{array}$ \\
\hline fta_merc & $\begin{array}{c}1.423 \\
(1.559)\end{array}$ & & $\begin{array}{c}1.454 \\
(1.645)\end{array}$ & & $\begin{array}{c}-0.243 \\
(0.695)\end{array}$ & $\begin{array}{c}1.261 \\
(1.148)\end{array}$ \\
\hline fta_anz & $\begin{array}{l}-3.008^{* * *} \\
(0.848)\end{array}$ & $\begin{array}{c}-2.920^{* * *} \\
(0.805)\end{array}$ & $\begin{array}{l}-3.020^{* * *} \\
(0.895)\end{array}$ & $\begin{array}{l}-2.936^{* * *} \\
(0.849)\end{array}$ & $\begin{array}{c}-0.492 \\
(0.442)\end{array}$ & $\begin{array}{c}-1.267 \\
(0.747)\end{array}$ \\
\hline Exporter FE & Yes & Yes & No & No & Yes & Yes \\
\hline Importer FE & Yes & Yes & No & No & Yes & Yes \\
\hline Year FE & Yes & Yes & Yes & Yes & Yes & Yes \\
\hline Country TV & No & No & Yes & Yes & No & No \\
\hline Estimator & OLS & OLS & OLS & OLS & PPML & Heckman \\
\hline$R^{2}$ & 0.582 & 0.582 & 0.608 & 0.608 & 0.753 & \\
\hline
\end{tabular}

Cluster-robust standard errors are reported in parentheses; ${ }^{\dagger,},{ }^{* *}$, and ${ }^{* * *}$ denote statistical significance at the $10 \%, 5 \%, 1 \%$ and $0.1 \%$ significance levels, respectively. $N=1519$; Dependent variable is $\ln \left(1+\right.$ trade) for columns (1)-(4) and (6); Pseudo $R^{2}$ is reported for the PPML results. 